\title{
Nutritionally Important Pigments in Purslane (Portulaca oleracea) Differ between Cultivars and in Response to Nitrogen
}

\author{
Dean A. Kopsell ${ }^{1,3}$, Kimberly J. Whitlock ${ }^{2}$, and Carl E. Sams ${ }^{1}$ \\ Department of Plant Sciences, The University of Tennessee, Knoxville, TN \\ 37996 \\ David E. Kopsell ${ }^{1}$ \\ Department of Agriculture, Illinois State University, Normal, IL 61790
}

Additional index words. $\beta$-carotene, chlorophyll, hydroponics, lutein, zeaxanthin

\begin{abstract}
Purslane (Portulaca oleracea) is a succulent weedy annual in much of the United States. In other parts of the world, purslane is grown as a specialty crop, valued for its nutritional quality. As a leafy crop, purslane contributes carotenoid phytochemicals in the typical Mediterranean diet. Nitrogen $(N)$ influences plant growth and alters pigment composition and accumulation. However, little is known about the impact $\mathrm{N}$ fertility may have on pigment concentrations in purslane shoot tissues. The objective of this study was to evaluate the influence of $\mathbf{N}$ fertility levels on biomass and concentrations of nutritionally important carotenoid and chlorophyll pigments in purslane. Green Leaf and Golden Leaf purslane cultivars were grown in nutrient solution culture under $\mathbf{N}$ concentrations of $13,26,52$, or $105 \mathrm{mg} \cdot \mathrm{L}^{-1}$. Plants were harvested at 45 days after planting (DAP), and measured for concentrations of shoot pigments using highperformance liquid chromatography (HPLC) methodology. There was no influence of $N$ treatment concentration on purslane shoot tissue fresh weight (FW) accumulation. Nitrogen treatment significantly influenced shoot tissue $\beta$-carotene (BC), lutein (LUT), neoxanthin (NEO), total carotenoids, chlorophyll $a$, chlorophyll $b$, total chlorophyll, and the chlorophyll $a$ to $b$ ratio in purslane shoot tissues. Concentrations of LUT, NEO, violaxanthin (VIO), chlorophyll $b$, total xanthophyll cycle pigments, and the chlorophyll $a$ to $b$ ratio differed between the purslane cultivars. Increases in $\mathbf{N}$ concentrations acted to increase concentrations of nutritionally important shoot tissue carotenoid pigments in only the Green Leaf purslane cultivar. Therefore, $\mathbf{N}$ fertility management and cultivar selection should be considered when producing purslane as a nutritious specialty vegetable crop.
\end{abstract}

Purslane $(P$. oleracea $)$ is a problematic succulent weedy annual in horticultural crop production in the United States (Armel et al., 2012). However, in other parts of the world purslane is grown as a specialty crop, valued for its nutritional quality. Regular consumption of a variety of specialty crops provides the human diet with essential vitamins and minerals, in addition to nutritionally important phytochemicals. Unique phytochemicals within these crops actively participate in chronic disease reductions, and can provide benefits beyond normal health maintenance (Shahidi, 2004). One such important group of phytochemicals is the tetraterpene carotenoids which function as accessory pigments in photosynthesis and prevent photooxidation in

Received for publication 12 Feb. 2016. Accepted for publication 22 Apr. 2016.

This research was made possible through support from the University of Tennessee Institute of Agriculture.

${ }^{1}$ Professor.

${ }^{2}$ Undergraduate Research Assistant.

${ }^{3}$ Corresponding author. E-mail: dkopsell@utk.edu. photosynthetic organisms (DellaPenna, 1999; Gross, 1991). Key roles of carotenoids in human nutrition are as vitamin A precursors and as macular pigment which protects against aging eye diseases (Combs, 1998; Johnson et al., 2000). Along with high concentrations of carotenoids, leafy specialty crops also contain high chlorophyll pigment concentrations (Ferruzzi and Blakeslee, 2007; Kopsell et al., 2004). Dietary chlorophyll may be nutritionally important in the reduction of intestinal absorption of potentially harmful chemical mutagens and carcinogens (Ferruzzi and Blakeslee, 2007; Natsume et al., 2004).

The effects of $\mathrm{N}$ supply on plant growth are well understood, and most economically important specialty crops have recommended rates for optimal yield. Nitrogen can alter plant composition more than any other essential element, and $\mathrm{N}$ is often the most limiting nutrient affecting growth in cropping systems (Barker and Mills, 1980; Hawkesford et al., 2012). Nitrogen can also influence phytochemical quality factors, and recent studies demonstrate that $\mathrm{N}$ can alter carotenoid and chlorophyll composition and accumulation in leafy specialty crops (Chenard et al., 2005; Kopsell et al., 2007;
Lefsrud et al., 2007). Purslane contributes nutritionally important phytochemicals, such as omega-3 fatty acids, organic acids, and various flavonoids, in the typical Mediterranean diet (Graça Dias et al., 2009; Su et al., 2002). Purslane can also accumulate high concentrations of carotenoid and chlorophyll pigments (Armel et al., 2012; Graça Dias et al., 2009; Su et al., 2002). However, little is known about the impact $\mathrm{N}$ fertility may have on concentrations of nutritionally important pigments in purslane shoot tissues. The objective of this study was to measure impacts of $\mathrm{N}$ fertility levels on carotenoid and chlorophyll pigment concentrations between two distinct purslane cultivars.

\section{Materials and Methods}

Purslane culture and harvest. Seeds of 'Golden Leaf' and 'Green Leaf' purslane (Richters, Ontario, Canada) were sown into $2.5 \times 2.5 \mathrm{~cm}$ rockwool growing cubes (Grodan $\mathrm{A} / \mathrm{S}$, Hedehusene, Denmark). The first experimental run was initiated on 15 May 2011, and a second experimental run was started on 26 June 2011. Seeds were germinated and greenhouse grown at $29^{\circ} \mathrm{C} /$ day and $22{ }^{\circ} \mathrm{C} /$ night under natural photoperiods at the University of Tennessee, Knoxville, TN $\left(35^{\circ} 58^{\prime} \mathrm{N}\right.$ lat.). After the emergence of the first true leaves $\approx 10 \mathrm{DAP}$, a $20 \mathrm{~N}-4.4 \mathrm{P}-16.6 \mathrm{~K}$ water-soluble fertilizer (Peter's 20-20-20; Scotts, Marysville, $\mathrm{OH}$ ) was applied every $3 \mathrm{~d}$ at a rate of $100 \mathrm{mg} \cdot \mathrm{L}^{-1} \mathrm{~N}$. Plantlets were transferred to containers (Rubbermaid Inc., Wooster, $\mathrm{OH}$ ) filled with $10 \mathrm{~L}$ of a modified nutrient solution 17 DAP. Elemental concentrations of the nutrient solutions were $\left(\mathrm{mg} \cdot \mathrm{L}^{-1}\right)$ : potassium (117.3), calcium (80.2), magnesium (24.6), sulfur (32.0), iron (0.5), boron (0.25), molybdenum (0.005), copper $(0.01)$, manganese $(0.25)$, and zinc $(0.025)$ (Hoagland and Arnon, 1950). The nutrient solutions were aerated via plastic tubing connected to an air blower (Model VB007S; Sweetwater, Fort Collins, CO). Plants were grown under increasing $\mathrm{N}$ concentrations of $13,26,52$, and $105 \mathrm{mg} \cdot \mathrm{L}^{-1}$. The $\mathrm{N}$ form ratio was kept constant at $1 \mathrm{NH}_{4}-\mathrm{N}: 3 \mathrm{NO}_{3}-\mathrm{N}$. Phosphorus level varied slightly with the $\mathrm{N}$ rate, changing from $91,89,86$, and $80 \mathrm{mg} \cdot \mathrm{L}^{-1}$ for the $\mathrm{N}$ treatment concentrations of 13,26 , 52 , and $105 \mathrm{mg} \cdot \mathrm{L}^{-1}$, respectively. Deionized (DI) water was added daily to maintain initial solution volumes in each container. The experimental design was a randomized complete block in a factorial arrangement of two cultivars by four $\mathrm{N}$ treatment concentrations. Containers acted as experimental units and each contained six individual plants of a single cultivar. Each cultivar/ $\mathrm{N}$ treatment combination was replicated four times, and solutions were replaced 31 DAP to refresh the solution to the initial nutrient concentrations. Plants were harvested 45 DAP in both experimental repeats and tissues were prepared for pigment analyses. At harvest, shoot and root tissue were separated, six plants in each cultivar/ $\mathrm{N}$ treatment combination were bulked, and FW was determined. Plant tissues were washed 
with a phosphate-free liquid detergent with neutral pH (Aquet; Bel-art Products, Pequannock, NJ), and were triple-rinsed with DI water. Shoot tissues were equally divided into two groups. One shoot tissue group and one root tissue group was placed in paper bags, and dried at $60{ }^{\circ} \mathrm{C}$ for no less than $72 \mathrm{~h}$, at which time dry weight (DW) was calculated, whereas the other shoot tissue group was stored at $-80{ }^{\circ} \mathrm{C}$ before lyophilization.

Purslane shoot tissue pigment extraction. Plant tissues were freeze-dried (model $6 \mathrm{~L}$ FreeZone; LabConCo, Kansas City, MO) at a constant temperature of $-20{ }^{\circ} \mathrm{C}$ before extraction. Pigments were extracted from freeze-dried tissues and analyzed according to Kopsell et al. (2012). A 0.1-g tissue subsample was rehydrated with $0.8 \mathrm{~mL}$ of ultrapure $\mathrm{H}_{2} \mathrm{O}$ for $20 \mathrm{~min}$. After incubation, $0.8 \mathrm{~mL}$ of the internal standard ethyl- $\beta-8$ 'apo-carotenoate (ChromaDex, Irvine, CA) was added to determine extraction efficiency. The addition of $2.5 \mathrm{~mL}$ of tetrahydrofuran (THF) was performed after sample hydration. The sample was then homogenized in a tissue grinding tube (Potter-Elvehjem; Kimble ChaseKontes Glass, Vineland, NJ) using $\approx 25$ insertions with a pestle attached to a drill press set at $540 \mathrm{rpm}$. During homogenization, the tube was immersed in ice to dissipate heat. The tube was then centrifuged for $5 \mathrm{~min}$ at $500 g_{\mathrm{n}}$. The supernatant was removed, the sample pellet was resuspended in 2-mL THF, and homogenized again with the same extraction technique. The procedure was repeated for a total of four extractions to obtain a colorless supernatant. The combined supernatants were reduced to $0.5 \mathrm{~mL}$ under a stream of $\mathrm{N}$ gas (N-EVAP 111; Organomation, Berlin, MA), and brought up to a final volume of $5 \mathrm{~mL}$ with acetone to dissolve all pigments. A 2-mL aliquot was filtered through a $0.2-\mu \mathrm{m}$ polytetrafluoroethylene (PTFE) filter (Econofilter PTFE 25/20; Agilent Technologies, Santa Clara, CA) before HPLC analysis.

Purslane shoot tissue pigment HPLC analysis. An HPLC unit with a photodiode array detector (1200 series; Agilent Technologies) was used for purslane pigment separation. Chromatographic separations were achieved using an analytical scale (4.6 i.d. $\times$ $250 \mathrm{~mm}) 5-\mu \mathrm{m}, 200-\AA$ polymeric $\mathrm{RP}-\mathrm{C}_{30}$ column (ProntoSIL; MAC-MOD Analytical, Chadds Ford, PA). The column was equipped with a $5-\mu \mathrm{m}$ guard cartridge $(4.0$ i.d. $\times 10 \mathrm{~mm})$ and holder (ProntoSIL), and was maintained at $30{ }^{\circ} \mathrm{C}$ using a thermostatted column compartment. All separations were achieved isocratically using a mobile phase of $11 \%$ methyl tert-butyl ether, $88.99 \%$ methanol, and $0.01 \%$ triethylamine (by volume). The flow rate was $1.0 \mathrm{~mL} \cdot \mathrm{min}^{-1}$, with a run time of $58 \mathrm{~min}$. Eluted compounds from a $10-\mu \mathrm{L}$ injection were detected at 453 (carotenoids and internal standard), 652 (chlorophyll $a$ ), and 665 (chlorophyll $b$ ) nm; and data were collected, recorded, and integrated using ChemStation Software (Agilent Technologies). Peak assignment for individual pigments was performed by comparing retention times and line spectra obtained from photodiode array detection using external standards [antheraxanthin (ANT), BC, Chlorophyll $a$, Chlorophyll $b$, LUT, NEO,VIO, and zeaxanthin (ZEA) from ChromaDex, Irvine, CA].

Statistical analyses. Data sets were analyzed using the General Linear Model procedure in SAS (version 9.2; SAS Institute, Cary, NC). The relationship between experimental dependent variables and $\mathrm{N}$ treatments were determined by regression analysis using the Regression procedure. Significant treatment by experimental run interactions were not detected in any of the biomass or phytochemical data. Thus, data from both experimental runs were combined and analyzed together.

\section{Results and Discussion}

Purslane shoot tissue FW and DW were not influenced by the main effects of $\mathrm{N}$ treatment concentration or purslane cultivar. Purslane root tissue FW was not influenced by $\mathrm{N}$ treatment concentration, but root $\mathrm{FW}$ varied by purslane cultivar $(P=0.001)$. Purslane root tissue DW was not influenced by $\mathrm{N}$ treatment concentration, but root $\mathrm{DW}$ was impacted by differences in purslane culti$\operatorname{var}(P=0.006$; Table 1$)$. None of the biomass parameters were impacted by the interaction of $\mathrm{N}$ treatment concentration and purslane cultivar. As the concentration of $\mathrm{N}$ in the nutrient solution was increased, linear increases were observed in 'Green Leaf' shoot tissue FW [grams per plant $=85.6+26.2(\mathrm{~N}$ trt $), r^{2}=$ $0.15, P=0.029$; Table 1].

Previously, kale (Brassica oleracea var. acephala) cultivars of Winterbor, Toscano, and Redbor demonstrated linear increases in shoot FW and DW and root FW and DW as N concentrations increased in nutrient solution culture from 6 to $105 \mathrm{mg} \cdot \mathrm{L}^{-1}$ (Kopsell et al., 2007). Moreover, Lefsrud et al. (2007) showed shoot tissue FW and DW in 'Springer F1' and 'Melody' spinach (Spinacia oleracea) to also increase in a linear manner in response to increases in $\mathrm{N}$ concentrations from 13 to $105 \mathrm{mg} \cdot \mathrm{L}^{-1}$ in nutrient solution culture. Chenard et al. (2005) showed that shoot tissue FW and DW for parsley (Petroselinum crispum) increased linearly in response to increases in $\mathrm{N}$ from 6 to $105 \mathrm{mg} \cdot \mathrm{L}^{-1}$ in nutrient solution culture. There are several possible reasons why increases in $\mathrm{N}$ treatment concentrations did not influence biomass accumulation in the purslane cultivars in this experiment as compared with previous studies, the first being plant biomass at harvest date. Kopsell et al. (2007) reported average biomass values for kale to range from $112 \mathrm{~g}$ per plant under $13 \mathrm{mg} \cdot \mathrm{L}^{-1} \mathrm{~N}$ concentrations to $250 \mathrm{~g}$ per plant under $105 \mathrm{mg} \cdot \mathrm{L}^{-1} \mathrm{~N}$ over 8 weeks; Lefsrud et al. (2007) reported average biomass values for spinach to range from $80 \mathrm{~g}$ per plant under $13 \mathrm{mg} \cdot \mathrm{L}^{-1} \mathrm{~N}$ concentrations to $350 \mathrm{~g}$ per plant under $105 \mathrm{mg} \cdot \mathrm{L}^{-1} \mathrm{~N}$ over 7 weeks; whereas Chenard et al. (2005) reported biomass values for parsley to range from $80 \mathrm{~g}$ per plant under $13 \mathrm{mg} \cdot \mathrm{L}^{-1} \mathrm{~N}$ concentrations to over $500 \mathrm{~g}$ per plant under $105 \mathrm{mg} \cdot \mathrm{L}^{-1} \mathrm{~N}$ over 11 weeks. Purslane in the current experiment was harvested 45 DAP. Plants displayed an upright
Table 1. Mean FW and DW for shoot and root tissues for 'Golden Leaf' and 'Green Leaf' purslane (Portulaca oleracea) grown under increasing $\mathrm{N}$ concentrations in nutrient solution culture. ${ }^{\mathrm{z}}$

\begin{tabular}{|c|c|c|c|c|}
\hline \multirow[b]{4}{*}{$\mathrm{N}\left(\mathrm{mg} \cdot \mathrm{L}^{-1}\right)$} & \multicolumn{4}{|c|}{ Purslane biomass } \\
\hline & \multicolumn{2}{|c|}{ Shoot tissue } & \multicolumn{2}{|c|}{ Root tissue } \\
\hline & FW & $\overline{\mathrm{DW}}$ & $\overline{F W}$ & DW \\
\hline & \multicolumn{4}{|c|}{ (g/plant) } \\
\hline & \multicolumn{4}{|c|}{ 'Golden Leaf' purslane } \\
\hline 13 & 23.68 & 1.04 & 0.79 & 0.06 \\
\hline 26 & 27.94 & 1.03 & 0.80 & 0.05 \\
\hline 52 & 25.11 & 1.09 & 0.83 & 0.05 \\
\hline 105 & 30.14 & 0.99 & 0.65 & 0.05 \\
\hline \multicolumn{5}{|l|}{ Regression ${ }^{\mathrm{y}}$} \\
\hline \multirow[t]{2}{*}{ Linear } & NS & NS & NS & NS \\
\hline & \multicolumn{4}{|c|}{ 'Green Leaf' purslane } \\
\hline 13 & 17.94 & 0.93 & 1.09 & 0.08 \\
\hline 26 & 24.21 & 1.09 & 1.24 & 0.08 \\
\hline 52 & 26.98 & 1.14 & 1.31 & 0.09 \\
\hline 105 & 31.56 & 1.22 & 1.44 & 0.09 \\
\hline \multicolumn{5}{|l|}{ Regression ${ }^{\mathrm{y}}$} \\
\hline Linear & $P=0.029$ & NS & NS & NS \\
\hline
\end{tabular}

$\mathrm{NS}=$ nonsignificant; FW = fresh weight; DW = dry weight; $\mathrm{N}=$ nitrogen.

${ }^{z}$ Values represent means for two complete experimental repeats, eight replications of composite shoot tissue samples for each purslane cultivar. SE estimates for 'Golden Leaf': shoot FW (3.63), shoot DW (0.16), root FW (0.10), and root DW (0.01). SE estimates for 'Green Leaf': shoot FW (4.38), shoot DW (0.21), root FW (0.27), and root DW (0.02).

${ }^{\mathrm{y}}$ Significance for linear regression over $\mathrm{N}$ fertility rates (equations can be found in the text).

growth habit, with limited lateral branching and leaf area. Production cycle timing and growth habit may have reduced the need for $\mathrm{N}$ in purslane growth and development and could be the reason that $\mathrm{N}$ did not impact biomass accumulation. This information may be helpful in the design of fertility programs for edible purslane production.

Accumulation of chlorophyll $a(P \leq 0.001)$, chlorophyll $b$ ( $P \leq 0.001)$, total chlorophyll $(P \leq 0.001)$, and the chlorophyll $a$ to $b$ ratio $(P=0.02)$ in purslane shoot tissues varied according to $\mathrm{N}$ treatment concentration. Only chlorophyll $b(P \leq 0.001)$ and the chlorophyll $a$ to $b$ ratio $(P \leq 0.001)$ in purslane shoot tissues were influenced by differences in purslane cultivar. Chlorophyll $a\left[\mathrm{mg} \cdot 100 \mathrm{~g}^{-1} \mathrm{FW}=87.8+7.0(\mathrm{~N}\right.$ trt $), r^{2}=$ $0.13, P=0.044]$ and total chlorophyll $\left[\mathrm{mg} \cdot 100 \mathrm{~g}^{-1}\right.$ $\mathrm{FW}=117.4+8.6(\mathrm{~N}$ trt $), r^{2}=0.13, P=$ $0.04]$ increased linearly in response to increasing $\mathrm{N}$ treatment concentrations for 'Golden Leaf' purslane (Table 2). Increasing $\mathrm{N}$ treatment concentrations resulted in linear increases in chlorophyll $a\left[\mathrm{mg} \cdot 100 \mathrm{~g}^{-1} \mathrm{FW}=\right.$ $39.8+23.4(\mathrm{~N}$ trt $\left.), r^{2}=0.33, P \leq 0.001\right]$, chlorophyll $b\left[\mathrm{mg} \cdot 100 \mathrm{~g}^{-1} \mathrm{FW}=27.7+4.8\right.$ $(\mathrm{N}$ trt $\left.), r^{2}=0.34, P \leq 0.001\right]$, total chlorophyll $\left[\mathrm{mg} \cdot 100 \mathrm{~g}^{-1} \mathrm{FW}=67.4+28.2(\mathrm{~N}\right.$ trt $)$, $\left.r^{2}=0.33, P \leq 0.001\right]$, and the chlorophyll $a$ to $b$ ratio $\left[\mathrm{mg} \cdot 100 \mathrm{~g}^{-1} \mathrm{FW}=1.6+0.3\right.$ (N trt), $\left.r^{2}=0.27, P=0.002\right]$ in 'Green Leaf' purslane shoot tissues (Table 2). Values measured for chlorophyll pigments within 'Green Leaf' and 'Golden Leaf' purslane were similar to data reported for weedy common purslane (P. oleracea) (Armel et al., 2012). 
Data are mounting on the role of dietary chlorophyll in the protection against harmful chemical mutagens and carcinogens (Ferruzzi and Blakeslee, 2007; Natsume et al., 2004). Therefore, additions of chlorophyll in diets may be nutritionally beneficial. Increasing $\mathrm{N}$ treatment concentrations acted to increase concentrations of valuable chlorophyll in both purslane cultivars in the current experiment. Increases were most dramatic for the Green Leaf cultivar (Table 2). Previously, Kopsell et al. (2007) demonstrated that increasing $\mathrm{N}$ concentrations from 6 to $105 \mathrm{mg} \cdot \mathrm{L}^{-1}$ in nutrient solution culture had no impact on the accumulation of chlorophyll pigments in three kale cultivars. Lefsrud et al. (2007) reported that increases in $\mathrm{N}$ concentrations in hydroponic production significantly increased chlorophyll pigments in only one of two spinach cultivars. Increasing $\mathrm{N}$ concentrations in nutrient solution culture caused significant increases in shoot tissue chlorophyll concentrations for 'Dark Green Italian' parsley (Chenard et al., 2005). Ammonia-N assimilation, the enzymatic activity of glutamine synthase isozymes (GS1 and GS2) and other intracellular transporters are linked with the chlorophyll biosynthesis pathway (Chatterjee and Kunda, 2015). Nitrogen is also a structural component of the chlorophyll molecule. Higher $\mathrm{N}$ treatment concentrations may have resulted in greater $\mathrm{N}$ uptake and translocation for chlorophyll biosynthesis within the purslane cultivars. High chlorophyll concentrations would improve the nutritional functionality of purslane.

Accumulation of BC $(P=0.01)$, LUT $(P=$ $0.003)$, NEO $(P=0.002)$, and total carotenoid pigments $(P=0.006)$ in purslane shoot tissues varied according to $\mathrm{N}$ treatment concentration. Shoot tissue concentrations of LUT $(P \leq 0.001)$, NEO $(P \leq 0.001)$, total xanthophyll cycle pigments [ZEA + ANT + VIO $(\mathrm{ZAV})](P=0.008)$, and the ratio of $\mathrm{ZEA}+\mathrm{ANT} / \mathrm{ZEA}+\mathrm{ANT}+\mathrm{VIO}(\mathrm{ZA} / \mathrm{ZAV})$ $(P=0.009)$ were influenced by differences in purslane cultivar. Increases in $\mathrm{N}$ treatment concentrations did not impact accumulation of any carotenoid pigment within shoot tissue of 'Golden Leaf' purslane (Table 3). However, BC $\left[\mathrm{mg} \cdot 100 \mathrm{~g}^{-1} \mathrm{FW}=4.2+0.7\right.$ ( $\mathrm{N} \mathrm{trt}$ ), $\left.r^{2}=0.26, P=0.003\right]$, LUT $\left[\mathrm{mg} \cdot 100 \mathrm{~g}^{-1} \mathrm{FW}=\right.$ $7.5+1.2(\mathrm{~N}$ trt $\left.), r^{2}=0.30, P=0.001\right], \mathrm{NEO}$ $\left[\mathrm{mg} \cdot 100 \mathrm{~g}^{-1} \mathrm{FW}=2.2+0.4(\mathrm{~N}\right.$ trt $), r^{2}=0.31$, $P=0.001]$, and total carotenoid pigment concentration $\left[\mathrm{mg} \cdot 100 \mathrm{~g}^{-1} \mathrm{FW}=17.1+2.7\right.$ ( $\mathrm{N}$ trt), $\left.r^{2}=0.27, P=0.002\right]$ all increased in a linear response to increases in $\mathrm{N}$ treatment concentrations in the 'Green Leaf' purslane (Table 3). Values measured for carotenoid pigments within 'Green Leaf' and 'Golden Leaf' purslane were similar to data reported for weedy common purslane (Armel et al., 2012); however, concentrations were higher for data previously reported for edible purslane (Graça Dias et al., 2009; Su et al., 2002).

The nutritional contributions of dietary carotenoid phytochemicals are as provitamin A compounds, photoprotection against aging eye diseases, and as antioxidants in chronic disease prevention. Purslane in the current

Table 2. Mean values for chlorophyll shoot tissue pigments in 'Golden Leaf' and 'Green Leaf' purslane (Portulaca oleracea) grown under increasing $\mathrm{N}$ concentrations in nutrient solution culture. ${ }^{\mathrm{z}}$

\begin{tabular}{|c|c|c|c|c|}
\hline \multirow[b]{3}{*}{$\mathrm{N}\left(\mathrm{mg} \cdot \mathrm{L}^{-1}\right)$} & \multicolumn{4}{|c|}{ Purslane shoot tissue chlorophyll pigments } \\
\hline & Chlorophyll $a$ & Chlorophyll $b$ & Chlorophyll $a+b$ & $a$ to $b$ ratio \\
\hline & \multicolumn{4}{|c|}{ (mg.100 $\mathrm{g}^{-1}$ fresh wt) } \\
\hline & \multicolumn{4}{|c|}{ 'Golden Leaf' purslane } \\
\hline 13 & 92.28 & 29.93 & 122.22 & 3.06 \\
\hline 26 & 107.25 & 34.59 & 141.83 & 3.12 \\
\hline 52 & 105.28 & 34.99 & 140.27 & 3.07 \\
\hline 105 & 116.16 & 35.22 & 151.38 & 3.30 \\
\hline \multicolumn{5}{|l|}{ Regression $^{\mathrm{y}}$} \\
\hline \multirow[t]{2}{*}{ Linear } & $P=0.044$ & NS & $P=0.040$ & NS \\
\hline & \multicolumn{4}{|c|}{ 'Green Leaf' purslane } \\
\hline 13 & 68.18 & 32.81 & 100.99 & 1.97 \\
\hline 26 & 86.82 & 38.47 & 125.29 & 2.24 \\
\hline 52 & 94.34 & 38.57 & 132.92 & 2.42 \\
\hline 105 & 143.64 & 48.78 & 192.43 & 2.94 \\
\hline \multicolumn{5}{|l|}{ Regression ${ }^{\mathrm{y}}$} \\
\hline Linear & $P \leq 0.001$ & $P \leq 0.001$ & $P \leq 0.001$ & $P=0.002$ \\
\hline
\end{tabular}

NS = nonsignificant; $\mathrm{N}=$ nitrogen.

${ }^{z}$ Values represent means for two complete experimental repeats, eight replications of composite shoot tissue samples for each purslane cultivar. SE estimates for 'Golden Leaf': chlorophyll $a$ (7.56), chlorophyll $b$ (2.09), chlorophyll $a+b$ (9.13), and $a$ to $b$ ratio (0.16). SE estimates for 'Green Leaf': chlorophyll $a$ (12.19); chlorophyll $b$ (2.70), chlorophyll $a+b$ (14.48), and $a$ to $b$ ratio (0.21).

${ }^{\mathrm{y}}$ Significance for linear regression over $\mathrm{N}$ fertility rates (equations can be found in the text).

Table 3. Mean values for carotenoid shoot tissue pigments in 'Golden Leaf' and 'Green Leaf' purslane (Portulaca oleracea) grown under increasing N concentrations in nutrient solution culture. ${ }^{\mathrm{z}}$

\begin{tabular}{|c|c|c|c|c|c|c|c|c|}
\hline \multirow[b]{3}{*}{$\mathrm{N}\left(\mathrm{mg} \cdot \mathrm{L}^{-1}\right)$} & \multicolumn{8}{|c|}{ Purslane shoot tissue carotenoid pigments } \\
\hline & $\mathrm{BC}$ & ZEA & LUT & ANT & $\mathrm{NEO}$ & $\mathrm{VIO}$ & Total CAR & $\overline{Z A} / \mathrm{ZAV}$ \\
\hline & \multicolumn{8}{|c|}{ (mg.100 $\mathrm{g}^{-1}$ fresh wt) } \\
\hline & \multicolumn{8}{|c|}{ 'Golden Leaf' purslane } \\
\hline 13 & 5.65 & 0.38 & 8.02 & 1.83 & 2.39 & 2.73 & 21.01 & 0.44 \\
\hline 26 & 6.37 & 0.34 & 9.20 & 1.74 & 2.81 & 3.45 & 23.91 & 0.39 \\
\hline 52 & 6.20 & 0.36 & 9.16 & 1.49 & 2.79 & 2.77 & 22.77 & 0.41 \\
\hline 105 & 6.25 & 0.38 & 9.18 & 1.64 & 2.75 & 2.96 & 23.15 & 0.41 \\
\hline \multicolumn{9}{|l|}{ Regression ${ }^{\mathrm{y}}$} \\
\hline \multirow[t]{2}{*}{ Linear } & NS & NS & NS & NS & NS & NS & NS & NS \\
\hline & \multicolumn{8}{|c|}{ 'Green Leaf' purslane } \\
\hline 13 & 5.07 & 0.33 & 8.96 & 1.42 & 2.64 & 1.94 & 20.36 & 0.50 \\
\hline 26 & 5.71 & 0.33 & 10.23 & 1.50 & 3.11 & 2.13 & 22.99 & 0.49 \\
\hline 52 & 5.69 & 0.37 & 10.20 & 1.39 & 3.03 & 1.90 & 22.56 & 0.50 \\
\hline & 7.40 & 0.41 & 13.12 & 1.89 & 3.98 & 2.80 & 29.60 & 0.45 \\
\hline \multicolumn{9}{|l|}{ Regression ${ }^{\mathrm{y}}$} \\
\hline Linear & $P=0.003$ & NS & $P=0.001$ & NS & $P=0.001$ & NS & $P=0.002$ & NS \\
\hline
\end{tabular}

NS = nonsignificant $\mathrm{BC}=\beta$-carotene $; \mathrm{ZEA}=$ zeaxanthin; $\mathrm{LUT}=$ lutein; $\mathrm{ANT}=$ antheraxanthin; $\mathrm{NEO}=$ neoxanthin; VIO = violaxanthin; Total $\mathrm{CAR}=$ total integrated carotenoid pigments; $\mathrm{ZA} / \mathrm{ZAV}=$ ratio of $\mathrm{ZEA}+\mathrm{ANT} / \mathrm{ZEA}+\mathrm{ANT}+\mathrm{VIO} ; \mathrm{N}=$ nitrogen.

${ }^{z}$ Values represent means for two complete experimental repeats, eight replications of composite shoot tissue samples for each purslane cultivar. SE estimates for 'Golden Leaf': BC (0.38), ZEA (0.06), LUT (0.53), ANT (0.17), NEO (0.17), VIO (0.33), Total CAR (1.26), and ZA/ZAV (0.04). SE estimates for 'Green Leaf': BC (0.48), ZEA (0.05), LUT (0.78), ANT (0.15), NEO (0.24), VIO (0.34), Total CAR (1.78), and ZA/ZAV (0.03).

${ }^{\mathrm{y}}$ Significance for linear regression over $\mathrm{N}$ fertility rates (equations can be found in the text).

study accumulated high concentrations of carotenoid phytochemicals. Increasing $\mathrm{N}$ concentrations in nutrient solution culture did not impact carotenoid concentrations in the shoot tissue of 'Golden Leaf' purslane. However, concentrations of BC, LUT, and total carotenoid pigments within the shoot tissues of 'Green Leaf' purslane all increased in response to increasing $\mathrm{N}$ treatment concentrations. Data support the presence of genetic variation for carotenoid metabolism in response to $\mathrm{N}$ fertility within available purslane germplasm. Therefore, $\mathrm{N}$ fertility management and cultivar selection should be considered when producing purslane as an edible specialty crop.

\section{Literature Cited}

Armel, G.R., D.A. Kopsell, J.J. Vargas, P.L. Rardon, M. Ruggiero, and S.A. Gower. 2012. Differential photosynthetic efficiency and pigment content in two common purslane (Portulaca oleracea) biotypes. Open Hort. J. 5:6-13.

Barker, A.V. and H.A. Mills. 1980. Ammonium and nitrate nutrition of horticultural crops. Hort. Rev. 2:395-424.

Chatterjee, A. and S. Kunda. 2015. Revisiting the chlorophyll biosynthesis pathway using genome scale metabolic model of Oryza sativa japonica. Scientific Rpt. 5:14975.

Chenard, C.H., D.A. Kopsell, and D.E. Kopsell. 2005. Nitrogen concentration affects nutrient and carotenoid accumulation in parsley. J. Plant Nutr. 28:285-297. 
Combs, G.F., Jr. 1998. The vitamins: Fundamental aspects in nutrition and health. 2nd ed. Academic Press, San Diego, CA.

DellaPenna, D. 1999. Carotenoid synthesis and function in plants: Insights from mutant studies in Arabidopsis thaliana, p. 21-37. In: H.A. Frank, A.J. Young, G. Britton, and R.J. Cogdell (eds.). The photochemistry of carotenoids. Vol. 8. Kluwer, Dordrecht, The Netherlands.

Ferruzzi, M.G. and J. Blakeslee. 2007. Digestion, absorption, and cancer preventative activity of dietary chlorophyll derivatives. Nutr. Res. 27: $1-12$.

Graça Dias, M., M. Filomena, G.F.C. Camões, and L. Oliveira. 2009. Carotenoids in traditional Portuguese fruits and vegetables. Food Chem. 113:808-815.

Gross, J. 1991. Pigments in vegetables: Chlorophylls and carotenoids. AVI/Van Nostrand Reinhold, New York.

Hawkesford, M., W. Horst, T. Kichery, H. Lambers, J. Schjoerring, I. Skrumsager Møller, and P. White.
2012. Functions of macronutrients, p. 135-150. In: P. Marschner (ed.). Marschner's mineral nutrition of higher plants. 3rd ed. Academic Press, London, UK.

Hoagland, D.R. and D.I. Arnon. 1950. The water culture method for growing plants without soil. California Agr. Expt. Sta. Circ. No. 347.

Johnson, E.J., B.R. Hammond, K.J. Yeum, J. Qin, X.D. Wang, C. Castaneda, D.M. Snodderly, and R.M. Russell. 2000. Relation among serum and tissue concentrations of lutein and zeaxanthin and macular pigment density. Amer. J. Clin. Nutr. 71:1555-1562.

Kopsell, D.A., D.E. Kopsell, M.G. Lefsrud, J. Curran-Celentano, and L.E. Dukach. 2004. Variation in lutein, $\beta$-carotene, and chlorophyll concentrations among Brassica oleracea cultigens and seasons. HortScience 39:361-364.

Kopsell, D.A., D.E. Kopsell, and J. Curran-Celentano 2007. Carotenoid pigments in kale are influenced by nitrogen concentration and form. J. Sci. Food Agr. 87:900-907.
Kopsell, D.A., N.I. Pantanizopoulos, C.E. Sams, and D.E. Kopsell. 2012. Shoot tissue pigment levels increase in 'Florida Broadleaf' mustard (Brassica juncea L.) microgreens following high light treatment. Sci. Hort. 140:96-99.

Lefsrud, M.G., D.A. Kopsell, and D.E. Kopsell. 2007. Nitrogen levels influence biomass, elemental accumulations, and pigment concentrations in spinach. J. Plant Nutr. 30:171-185.

Natsume, Y., H. Satsu, K. Kitamura, N. Okamoto, and M. Shimizu. 2004. Assessment system for dioxin absorption in the small intestine and prevention of its absorption by food factors. Biofactors 21:375-377.

Shahidi, F. 2004. Functional foods: Their role in health promotion and disease prevention. J. Food Sci. 69:R146-R149.

Su, Q., K.G. Rowley, C. Itsiopoulos, and K. O’Dea. 2002. Identification and quantitation of major carotenoids in selected components of the Mediterranean diet: Green leafy vegetables, figs and olive oil. Eur. J. Clin. Nutr. 56:1149-1154. 